Discussion Paper No. 97-17

\title{
Relative Earnings and the Demand for Unskilled Labor in West German Manufacturing
}

\author{
Viktor Steiner \\ Kersten Wagner
}




\title{
Relative Earnings and the Demand for Unskilled Labor in West German Manufacturing
}

\author{
von \\ Viktor Steiner \\ Kersten Wagner \\ Zentrum für Europäische Wirtschaftsforschung (ZEW) \\ Centre for European Economic Research
}

Juni 1997

\begin{abstract}
We analyze the economic factors which have contributed to the dramatic decline of the employment share of unskilled labor in German manufacturing, in particular the role played by the relatively rigid earnings structure. Potential effects of intensified international competition and skill-biased technological change on the relative employment and earnings position of unskilled workers are also discussed. We find that the substitution elasticity between unskilled and skilled labor is rather low. The decline in the employment share of unskilled workers attributable to an inflexible earnings structure therefore seems to have been modest compared to the trend decline in the skills ratio. We also find some modest effects from international competition and technological change on the employment share of unskilled labor.
\end{abstract}

\section{JEL classification: J23, J31}

\section{Acknowledgement}

We thank Bertrand Koebel for providing us with national accounts data and his estimates of total productivity growth and user costs of capital. Bernd Fitzenberger and Lawrence Mishel provided helpful comments on an earlier version of this paper presented at the conference "Globalization, Technological Change, and the Welfare State", American Institute for Contemporary German Studies, The Johns Hopkins University, June 9 - 10, 1997, Washington, D.C. Of course, all remaining errors are our sole responsibility. 


\section{Non-technical Summary}

The U.S. labor market and its employment performance over the last twenty years or so is often cited as a model for some of the European countries, and Germany in particular. While the U.S. economy has been more successful in creating jobs for the unskilled than the German economy, this seems to have come at the cost of a dramatic increase in earnings inequality in the U.S. which has hardly changed in Germany. These differential labor market developments in the U.S. and Germany seem to support the hypothesis of a trade-off between more jobs for unskilled workers on the one hand, and a less equal earnings distribution on the other. However, the few empirical studies which try to test this hypothesis for various countries have failed to provide conclusive results. For Germany, there has so far been very little research on the empirical importance of this alleged trade-off.

In this paper, we analyze the economic factors which have contributed to the dramatic decline of the employment share of unskilled labor in German manufacturing, in particular the role played by the adjustment of relative earnings to increased international competition and technological change. Although the reduction in the relative supply of unskilled labor has certainly contributed to this development, it is only part of the story. The decline in the demand for unskilled relative to skilled labor (skills ratio) has also played an important role. On the basis of a simple econometric model, we find a trend decline in the skills ratio in the whole manufacturing sector of $3 \%$ per year. The estimated substitution elasticity from our preferred specification of the relative labor demand function implies that a reduction of the earnings of unskilled relative to skilled workers by $10 \%$ would increase the relative employment level of the unskilled on average by about $3 \%$.

As to the potential effects of intensified international competition and technological change, we have found some evidence for the hypothesis that the relative employment of unskilled workers in industries with high import shares has declined more strongly than in those little affected by international competition, but the size of this effect is not dramatic. There is also some evidence which seems to support the hypothesis that the relative employment decline of unskilled workers in industries characterized by relatively high rates of technological change has been somewhat stronger than on average, but this effect, too, explains relatively little of the overall decline in the skills ratio.

Given these estimates of the trend decline in the skills ratio and the substitution elasticity, even reductions in the relative earnings of unskilled workers on a scale observed for the U.S. labor market in the 1980's would not be sufficient to bring employment of unskilled workers in West German manufacturing back to the levels we observed in the past. At best, feasible reductions in the relative earnings of 
unskilled workers would counter the further decline in the employment share of unskilled labor to some extent.

\begin{abstract}
"The rise in joblessness is thus the flip side of the rise in earnings inequality in the U.S. The two outcomes reflect the same phenomenon-a relative decline in the demand against the less skilled that has overwhelmed the longterm trend decline the relative supply of less-skilled workers. In the United States, where wages are highly flexible, the change in the supply-demand balance lowered the wages of the less skilled. In Europe, where institutions buttress the bottom parts of the earnings distribution, the change produced unemployment."
\end{abstract}

(Freeman, 1995, p. 19)

\section{Introduction}

Nowadays it has become fashionable among economists and policy makers alike to point to the U.S. labor market and its employment performance over the last twenty years or so as a model for some of the European countries, and Germany in particular. Critics of this view do not dispute that, in terms of new jobs created, the U.S. labor market has outperformed European countries by a wide margin, but stress that employment growth in the U.S. has been concentrated on low-productivity jobs in the service sector which do not earn enough to provide a decent standard of living. Empirical evidence for this assertion is provided by the widely documented fact that earnings inequality in the U.S. has sharply increased since the early 1980's due to the deterioration of the earnings position of unskilled labor relative to college graduates. In contrast, earnings inequality in welfare states of the type prevailing in most western European countries has changed very little in this period.

Germany ${ }^{1}$ is one particularly instructive example of a welfare state where the level of unemployment markedly increased in the 1980's but the distribution of earnings changed little (see Steiner and Wagner, 1996). This raises the question, why? After all, the factors for the increase in earnings inequality usually cited in the literature, such as changes in the demographic structure of the work force, international trade with low-wage countries and skill-biased technological progress (for surveys of the literature see, e.g., Levy and Murane, 1992; Burtless 1995) should have affected the German and the U.S labor markets in a similar way. Conventional wisdom holds that these factors have been accomodated by different price and quantity adjustments in the two countries: whereas they have changed the wage structure in

1 Here and in the following, Germany always refers to West Germany prior to unification in 1990. 
the United States, they have led to employment adjustment in Germany. This difference is usually explained by the much greater importance of institutional factors in Germany, such as effective wage floors set by collective bargaining agreements, unions' "solidaristic wage policy" aiming at uniform relative wage increases, and income support schemes characterized by high earnings replacement ratios together with the widespread use of early retirement schemes (see, e.g., Abraham and Houseman, 1995, Siebert, 1997).

In this view, the differential labor market developments in the U.S. and Germany support the hypothesis of a trade-off between more jobs for unskilled workers on the one hand, and a less equal earnings distribution on the other. However, very little hard evidence seems to be available to support—or to reject—-this hypothesis, and the few empirical studies which exist in this area come up with inconclusive or conflicting results. For a small cross-section of developed market economies, the OECD (1996) reports a significant negative relationship between unemployment rates and a measure of the degree of inequality prevailing in the lower part of a country's earnings distribution. This correlation disappears, however, when firstdifferences of unemploment rates and the inequality measure rather than their levels are considered. In a study covering a larger number of countries, Blau and Kahn (1996) find that employment ratios of low-skilled workers are lower in countries with a more compressed earnings distribution than the U.S., but this correlation seems far from conclusive, to say the least. After comparing the development of relative unemployment rates and wages for various skill groups in a number of OECD countries, Nickell and Bell (1995, p. 46) conclude that "there seems to be no evidence for relationship between the unemployment rate effects [of the fall of the relative demand for unskilled workers] are any more severe in countries where the wage effects are small". Furthermore, in an econometric comparative study including the U.S., Canada and France, Card, Kramarz and Lemieux (1996) found little evidence for the hypothesis that the more compressed earnings distribution in France, which hardly changed in the observation period, generated significantly different employment trends than in the other two countries characterized by a higher degree of wage flexibility. However, this seems to be at odds with the rather high absolute values of the estimated substitution elasticity between skilled and unskilled workers reported in Goux and Maurin (1996, 1997).

Except for the study by Krueger and Pischke (1997), who found no relationship between the change in the employment-to-populations ratio disaggregated by a small number of age-education cells and the respective wage in the base period, the empirical relationship between relative employment growth and earnings inequality has apparently not been analyzed for Germany so far. This paper tries to partially fill this gap. We analyze the economic factors which have contributed to the dramatic decline of the employment share of unskilled labor in German manufacturing, in particular the role played by the adjustment of relative earnings to 
increased international competition and technological change. To this end, we provide some theoretical and institutional background in section 2, while section 3 presents some stylized facts on employment and wage trends. Section 4 contains a brief description of the empirical model and the estimation results, and in section 5 we draw some conclusions.

\section{Theoretical and Institutional Background}

The supply of unskilled workers and their share in overall employment have markedly decreased in developed economies over time. In most of these countries, this development was accompanied by a concomitant deterioration of the earnings position of unskilled relative to skilled workers, for which the U.S. economy is the typical example. On the other hand, in Germany the decline in the relative supply and employment of unskilled labor was particularly strong, but the earnings distribution changed little. These stylized facts can be explained by differential shifts in the relative demand for skills overcompensating the decline in the relative supply and country differences in the adjustment of relative wages. Hence, one needs to identify the economic factors affecting the relative demand for skills and the institutional factors explaining the differences in labor market adjustments.

Given that shifts in the relative demand for skills have led to the observed trends in the employment of unskilled labor, what are the economic forces for these demand shifts? Since the deterioration of the relative labor market position of unskilled workers is a long-time phenomenon, it seems unlikely that cyclical factors could have played an important role in this development. The main candidates among the factors which may have reduced the demand for unskilled labor are international competition and skill-biased technological change. These factors are likely to be of special importance in the case of Germany because its economy is highly dependent on international trade in manufactured goods which embody a high degree of human capital.

The partial-equilibrium effects of more intense international competition, usually viewed as an increase in the share of imports from low-wage countries ("globalization"), and technological change on the relative employment and earnings position of unskilled workers in the domestic economy can be analyzed on the basis of a straightforward extension of the standard demand-supply framework (see, e.g., Nickell and Bell, 1995, Goux and Maurin, 1997). These effects depend on the slope of the relative demand curve for unskilled and skilled labor, that is the substitution elasticity between these two groups, the position and slope of their respective supply curves, and the extent to which trade and technological shocks shift the relative demand curve for labor. This depends on the pricing behavior of firms and the effects of these shocks on relative output prices, which are typically 
not modelled within this partial-equilibrium setting. The extent to which reductions in the relative demand for skills will be transmitted into, respectively, a lower employment share and a deterioriation of the relative earnings position of the unskilled will depend on wage setting behavior and thus the structure of the labor market.

This partial equilibrium analysis has been criticized by trade economists who stress the general-equilibrium effects of increased international trade on the domestic labor market (see, e.g., Richardson, 1995, Leamer, 1996; for a survey see Burtless, 1995). Here, the analysis is usually cast in terms of a slightly modified version of the Heckscher-Ohlin-Samuelson (HOS) model of international trade with two countries using, respectively, unskilled and skilled labor intensively in the production of two goods. In this framework, changes in relative product prices are the main channel through which trade affects the domestic labor market. Hence, the relationship between relative earnings and employment shares of unskilled and skilled labor on the one hand, and relative product prices on the other play the central role in the HOS world.

Assuming the domestic economy is richly endowed with skilled labor and thus has a comparative advantage in the production of skill-intensive ("high-tech") goods, the opening-up of trade with low-skill countries ("globalization") will result in an increase of the relative price of the high-tech good. Given flexible relative wages, this, in turn, will decrease the earnings of unskilled relative to skilled labor and increase the employment share of unskilled workers, the skills ratio for short, in both sectors. In the new equilibrium, both groups of workers will be fully employed.

The adjustment of the labor market to "globalization" by changes in relative wages rather than (un-)employment has been termed the "American scenario" and contrasted to the "European scenario" by Krugman (1995a). In this world, relative wages are inflexible and globalization does not change relative prices. Not surprisingly, the skills ratio in both sectors of the domestic economy also remains unchanged and, since the demand for domestically produced low-tech goods is reduced, employment of unskilled labor declines and unemployment results.

The labor market effects of skill-biased technological change also differ between these two scenarios (Krugman, 1995b, Landmann and Pflüger, 1996). In the "American scenario", unskilled labor-saving technological change will reduce relative earnings as well as the skills ratio in both sectors of the domestic economy without increasing unemployment among the unskilled. In the "European scenario", skill-biased technological change will reduce the skills ratio in both sectors and, given the assumed inflexibility of relative wages, will increase unemployment among unskilled workers. 
To sum up, in theory both increased international competition and skill-biased technological change may affect relative earnings and/or employment of unskilled workers, and these effects crucially depend on assumptions about wage setting behavior. However, there is no agreement on the relative importance of these factors. In fact, it's not even clear whether the labor market effects of intensified trade and technological change can be identified separately, since the former should affect the latter and vice versa (see, e.g., Richardson, 1995, Wood, 1995).

Some attempts have been made to empirically distinguish between these effects, where most studies are concerned with wage rather than employment effects of international trade and skill-biased technological change. ${ }^{2}$ Most empirical studies for the U.S. seem to conclude that skill-biased technological change rather than higher imports from low-wage countries have contributed to a deterioration of the relative earnings or employment position of unkilled workers. However, it seems fair to say that the evidence in favor of the technological change argument is anything but conclusive, not the least because most authors simply equate this factor with the unobserved variation within skill groups and/or industries or, in a regression framework, to the unexplained residual.

In Germany, the earnings distribution has changed very little in the 1980's, if at all (Steiner and Wagner, 1996), and there also seem to have been little changes over the longer term (Becker, 1996). The small increase in earnings inequality which occurred in the second half of the 1980's was not related to a widening earnings differential between skilled and unskilled labor; if anything, the return to an occupational qualification relative to unskilled work even decreased in this period (Steiner and Wagner, 1996). Given these facts, it comes as no surprise that Fitzenberger (1996) finds no negative effects from technological change and trade on the relative earnings position of unskilled relative to skilled workers. ${ }^{3}$

2 See, e.g., Bound and Johnson (1992), Katz and Murphy (1992); for summaries see Levy and Murnane (1992), and Burtless (1995). Since this literature primarily focuses on the U.S. labor market where these shocks are mainly absorbed by the adjustment of relative wages, their employment implications are typically not explicitely discussed very much (an exception is the study by Berman, Bound and Griliches, 1994). However, the results of these studies naturally have direct implications for the determination of the employment of unskilled relative to skilled labor as well. In contrast, the German literature stresses the (un-)employment effects of international competition and technological change (see, e.g., Hesse, 1996, Blattner, 1996), although there is little empirical evidence on these effects available for Germany.

3 As to the effect of technological change on relative earnings, the results obtained by Fitzenberger (1996) are in conflict with those reported in Möller (1996), which seem to be affected by measurement error in the earnings variable, however (see Steiner and Wagner, 1996). 
The difference between the labor market response in Germany and the U.S. to increased import competition from low-wage countries and skill-biased technological change is usually portrayed as quantity versus price adjustment in the labor market, that is higher unemployment or non-employment rates of unskilled workers on the one hand, and increasing earnings inequality on the other. The rigidity of the German earnings structure is typically explained by the greater importance of institutional regulations, i.e. strong German trade unions and income support schemes (see, e.g., Abraham and Houseman 1995, Siebert, 1997). Some institutional background on the German bargaining and welfare system therefore seems appropriate here.

In contrast to the U.S., German wage bargaining is centralized and characterized by stong unions organized by industry and region. ${ }^{4}$ Even though only about one third of all German workers are union members, coverage of wages by collective bargaining agreements is quite widespread. In member firms of an employers' organization covered by a collective bargaining agreement the contract wage is usually also paid to non-union members of the workforce, although this is not legally binding. For whatever reason, many firms not formally belonging to an employers' organization also pay the bargained industry wage. Furthermore, the Federal Minister of Labor and Social Affairs can make the contract wage also binding for non-member firms in case such a regulation is considered to be in "the public interest" provided representatives of the collective bargaining parties chosen from other industries unanimously agree. One of the official aims of some of the German unions, especially the powerful metal workers union which covers a large part of the manufacturing sector, has been to follow a policy of equalizing differences in earnings aiming at uniform relative wage increases, which is known as "solidaristic" wage policy.

Another institutional feature which may excert some influence on the downwardflexibility of earnings, especially for unskilled workers, is the German income support system including early retirement schemes, unemployment insurance and social assistance. ${ }^{5}$ Early retirement schemes have been used extensively in the 1980 's as a means of labor force adjustment, especially in the manufacturing sector. At the same time, entitlement periods to unemployment benefits were extended substantially for older workers and often used as a way to bridge the time before reaching the earliest possible retirement age, usually at 60 years after a spell of long-term unemployment. Depending on age and previous labor market experience, benefit entitlement periods are quite long in Germany, and means-tested

4 For more detail on the German wage bargaining system see, e.g., Bellmann and Möller (1995) and Franz (1995).

5 A good summary of the German welfare state is contained in Hauser (1995). 
unemployment assistance is open-ended in principle. Furthermore, the coverage rate of the German unemployment insurance system is relatively high by international standards. ${ }^{6}$ Those not covered by it can apply for social assistance, which is means-tested and provides a minimum standard of living for the household. For families with children its level may well come close or even exceed earnings of a full-time unskilled worker in the lower part of the distribution. Although there is some suspicion that these measures have excerted an important influence on wage setting and the level of unemployment in Germany (see, e.g., Siebert, 1997), there seems to be hardly any empirical evidence to support this claim.

\section{Some Stylized Facts}

To set the scene for the following empirical analysis, we first present some stylized facts on employment and earnings trends in West Germany. To begin with, we first describe some general trends referring to the whole economy. For the reasons set out below, most of the subsequently presented evidence refers to male workers in manufacturing in the period 1975 to 1990, for which individual-level earnings information differentiated by skills is available.

Between the recession year 1975 and the pre-unification year 1990, overall employment in West Germany increased by almost $14 \%$ from 22,4 to 25,5 millions, where the strongest increase occurred in the second half of the eighties, when about 2 million jobs net were created. Strongly influenced by the unification boom, employment growth accelerated at the beginning of the nineties and West German employment reached an all-time high of over 26 millions in 1992. In 1993/1994, the economy was hit by a severe recession resulting in large-scale employment reductions. Between 1992 and 1996, employment dropped by about one million persons and has now reached its pre-unification level. Since labor supply increased strongly throughout the period, even the relatively strong employment increase in the second half of the eighties was insufficient to bring down overall unemployment to its level before the recession of the early eighties. ${ }^{7}$ In 1990, the unemployment rate as measured by the OECD stood at $6 \%$, compared with a level of $4 \%$ in the recession year 1975. It has increased to $8 \%$ after the recession in 1993/94. ${ }^{8}$

6 The German unemployment insurance system is briefly described in Hunt (1995) and Steiner (1997), who also analyze its effects on the duration of unemployment.

7 These and, if not otherwise stated, the following facts are taken from the Official Bulletin of the Federal Labor Office (Amtliche Nachrichten der Bundesanstalt für Arbeit), various issues.

8 Franz (1997) provides a comparative analysis of the German and U.S. labor markets. 
The increase of unemployment in the 1980's mainly occurred among the unskilled and older male workers. The strong increase in female labor supply did not result in higher unemployment of women, but an increasing share of female employment throughout the period. In the high-growth period in the second half of the 1980's alone, the share of females in employment increased by 5 percentage points. This increase was both related to changes in educational attainment of females, the expansion of the service sector and the extension of female part-time work. Between 1985 and 1990 the service sector expanded by more than 2 million employees, while the share of females in this sector increased from about 55 to 60 percent. The share of part-time employed among all female employees increased by about 5 percentage points to 36 percent in this period, where part-time employment is concentrated in services and the public sector. ${ }^{9}$

In the period from the mid-1970's to the end of the 1980's, employment of unskilled workers in the whole West German economy dropped by almost 36\%, while the number of skilled employees increased by 30\%. Employment losses for the unskilled in manufacturing were markedly higher than in the service sector, but even there employment of this group dropped by more than $20 \%$. Within the manufacturing sector, these employment losses ranged from $35 \%$ in industries producing investment goods to almost 50\% in mining and energy production (see Sachverständigenrat 1994, Table 51).

To what extent have demand and supply factors contributed to these employment trends? Based on a shift-share analysis, Abraham and Houseman (1995) try to attribute the change in the relative demand for workers of different skill groups to changes in the sectoral composition of employment. They conclude that, due to shifts in the sectoral distribution of employment, the demand for unskilled workers markedly decreased, while the demand for workers with an occupational qualification increased substantially in the 1970's. According to their calculations, the demand for skilled labor kept on increasing in the 1980's at roughly the same pace as in the previous period, while the demand for unskilled labor stagnated. On the supply side, the share of the population aged between 20 and 60 years with an occupational qualification (apprenticeship training and technical school degrees) increased from $55 \%$ in the mid-seventies to about $63 \%$ at the end of the eighties, while the percentage of unskilled people decreased from about $40 \%$ to about $28 \%$ of the population (Abraham and Houseman, 1995, Table 11.10). ${ }^{10}$

9 The mentioned facts on sectoral employment developments by gender are documented for the period 1980 to 1994 in Steiner and Kaltenborn (1995).

10 The unskilled category also includes those who didn't answer to the questions on educational attainment. 
In the light of the general labor market developments described above, the German unemployment problem seems to be closely related to the relative decline of employment in manufacturing, in particular of unskilled males. In the following, we therefore focus on the development of skill-specific trends in employment and earnings of males in the period 1975 to 1990. The data set used here and also for the regression analysis in the next section derives from merging data from the disaggregated national accounts for two-digit manufacturing industries and individual-level employment and earnings information from social security records for the period 1975 to 1990 . The main advantage of the social security data for the present purpose is that it allows us to calculate employment shares and earnings ratios for meaningful skill groups and also by labor market experience. ${ }^{11}$

Here we distinguish between three skill groups, namely unskilled workers, skilled workers and graduates. We define workers as unskilled if they neither have obtained a vocational qualification (apprenticeship) nor a degree in higher education. Workers with a vocational degree and/or university entry level degree are classified as skilled. Graduates include those with an university degree or a polytechnical degree. While the number of skilled male workers in manufacturing slightly increased after the recession in the mid-seventies and then remained fairly constant, employment of unskilled labor decreased and of graduates increased throughout the whole period. The employment decline of the unskilled also seems to have accelerated in the eighties, while the growth in employment of graduates was particularly strong in the second half of the decade. Nevertheless, it seems unlikely that graduates have been substituted for unskilled labor, and our interest in the following will focus on the development of the ratio of unskilled workers to skilled workers, the skills ratio for short.

Between 1975 and 1990, this average (male) skills ratio in manufacturing has declined from 0.46 to 0.30 (see Figure 1). Although levels at the beginning of the observation period and the time pattern differ substantially, the skill ratio exhibits a strong negative trend in all manufacturing industries. Simple regressions show that the skills rate declined by an average rate of almost $3 \%$ per year ranging from almost $6 \%$ in the airlines industry to less than $0.2 \%$ in printing and publishing (the coefficient of variation is 0.436 ). In contrast, the overall ratio of median earnings of

11 The differentiation between, respectively, production/non-production or blue-/white-collar workers often found in the U.S. literature is, in our opinion, not a useful one, at least for the German situation. Another possible differentiation used in German studies is based on the qualification grouping ("Leistungsgruppen") found in collective bargaining agreements, which differentiates between three blue-collar and four white-collar groups (see, e.g., Entorf, 1996 for a recent study). However, this classification does not differentiate workers by their level of labor market experience. 
unskilled to skilled workers in manufacturing remained fairly stable within the observation period. We use median rather than average earnings here because the latter are affected by the change in the coding of fringe benefits in the social security data in 1983/84 (see the appendix). There are substantial differences in this earnings ratio between manufacturing industries, which changed little over time. Although absolute changes in the earnings ratio were generally very small, they do differ between industries (the coefficient of variation is 2.1). For the 1980's, the overall stability of the earnings distribution has also been confirmed by Steiner and Wagner (1996) who also show that the average earnings differential between skilled and unskilled workers has become even slightly smaller in the observation period..

Figure 1 Skills ratio and earnings ratio in manufacturing (males).

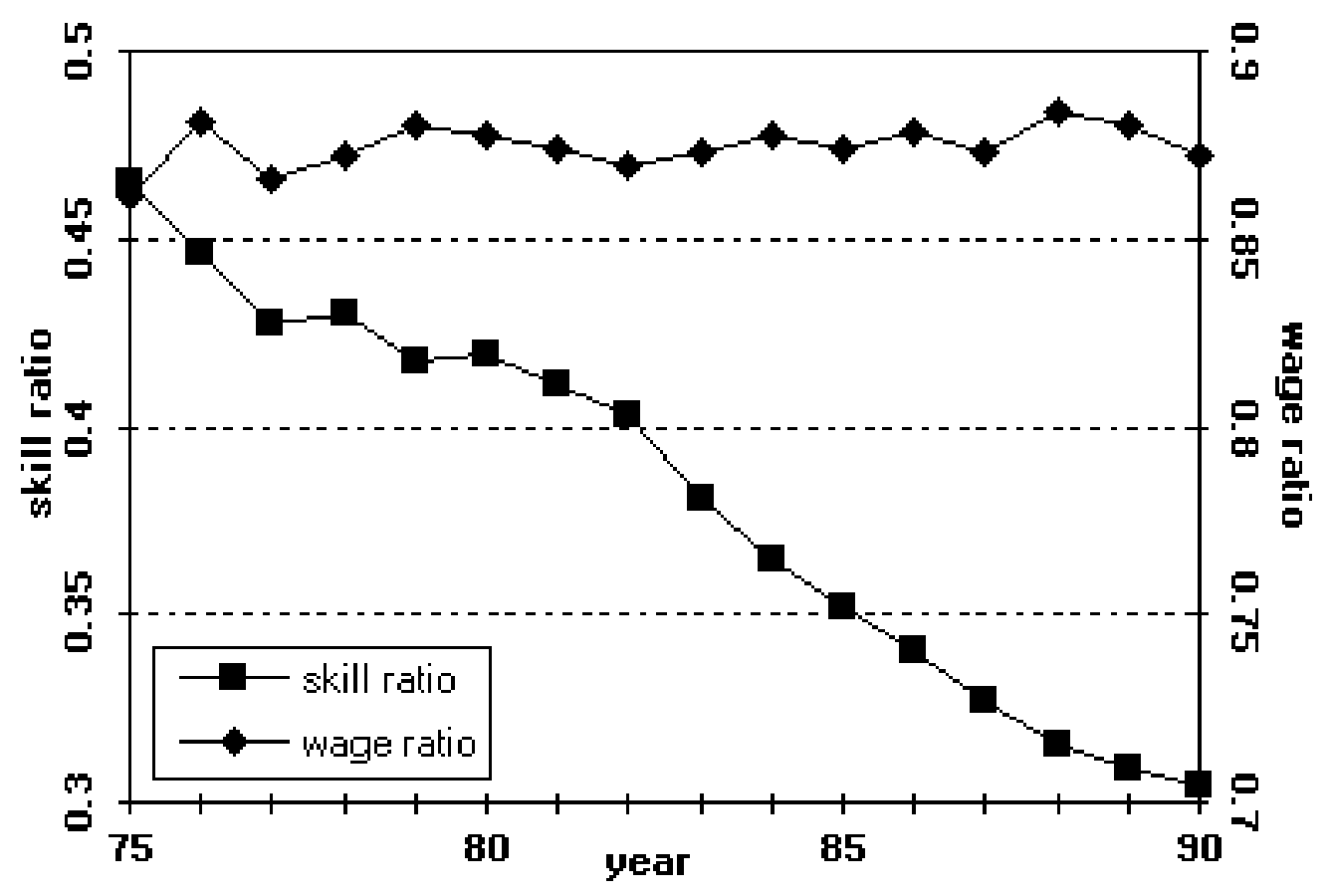

Note: For the definition of industry classes see the appendix.

Source: IABS data, own calculations.

As mentioned in section 2, increased imports from low-wage countries may have had negative effects on earnings and/or employment of unskilled workers. To get some indication on the existence of such effects, we have disaggregated the whole manufacturing sector into four subsectors defined by the quartile an industry's import share belongs to. ${ }^{12}$ Figure 2 plots the development of the skill and earnings ratios for the resulting four subgroups over time. There is still a strong overall

12 We divided the observation period into three sub-periods (1975 - 1979, $1980-1984$, and 1985 - 1990) and compared the relative position of each industry over time. We found that there was very little change in the industry ranking of import ratios in the observation period. 
negative trend of the skill ratio, but the relative decline of the share of unskilled workers differs between these industry subgroups. For the industries with the lowest import share the ratio of unskilled to skilled workers declined by $29.6 \%$, while it dropped by about $40 \%$ in the $25 \%$ of industries with the highest import shares. On the other hand, the ratio of median earnings increased in industries with relatively low import shares, while unskilled workers in industries more heavily affected by international trade experienced a modest decline in their relative earnings. Hence, the overall stability of the earnings ratio seems to result to some extent from compensating trends in industries which are differently affected by international competition. 
Figure 2 Skills ratio and earnings ratio for industries classified by import intensity.
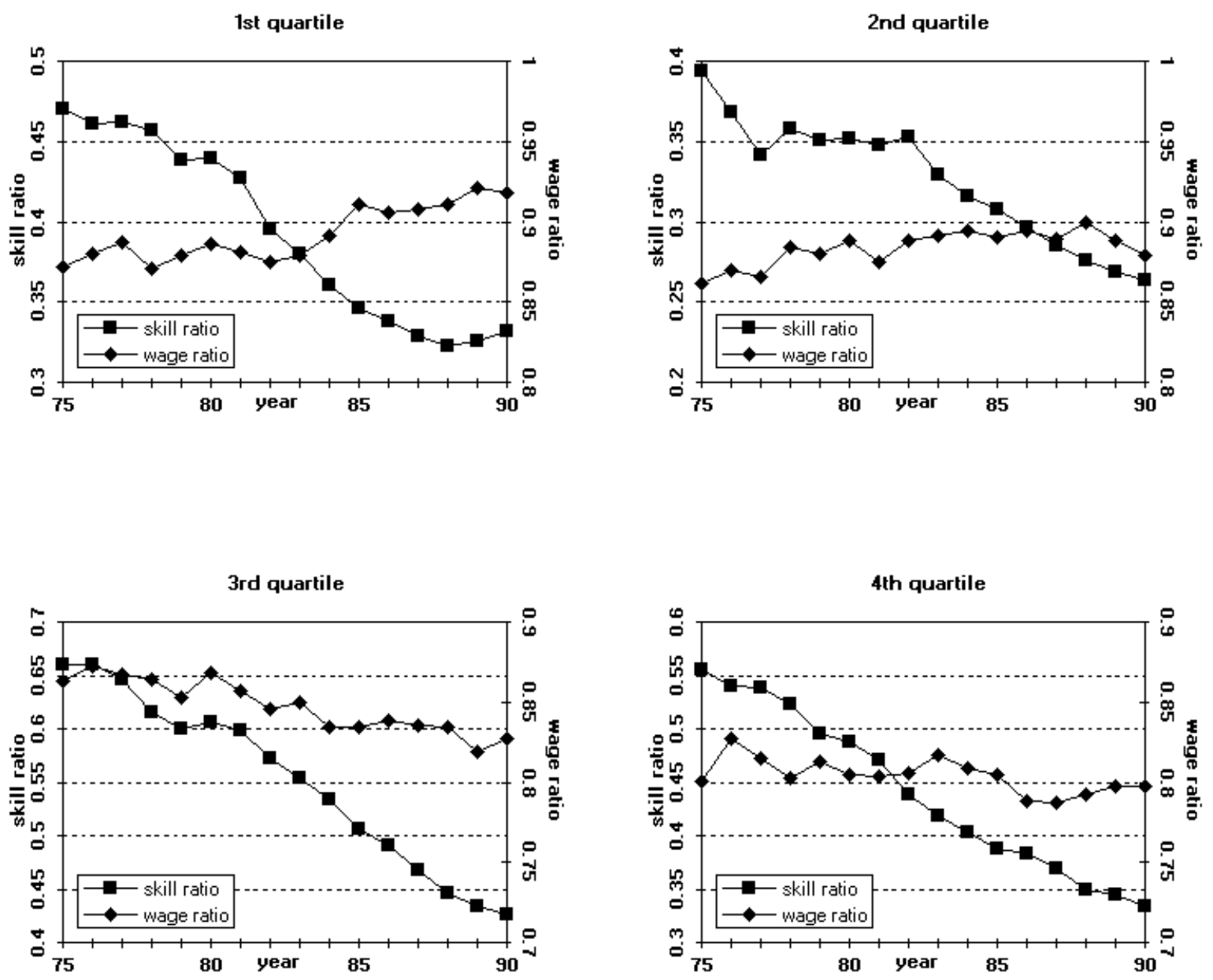

Source: IABS data, own calculations.

As to the other factor which is generally considered to have played an important role in the development of the relative employment and earnings position of unskilled workers, no directly observable measures of technological change seems to be available for Germany covering our observation period. ${ }^{13}$ We therefore use a measure of total factor productivity growth at the industry level as an indicator for technological change here. Based on this measure, we have grouped the two-digit manufacturing industries into four subsectors defined by the average rate of total factor productivity growth in the observation period. ${ }^{14}$ As Figure 3 shows, the share

13 Möller and Bellmann (1996) use survey data on innovative activity collected by the ifo-institute, Munich, and find some correlation between indicators of process and product innovation and earnings differentials by broad skill group. These data were not available to us.

14 We thank our colleague Bertrand Koebel for providing us with his calculations of total factor productivity growth at the industry level. The industries were grouped according to their 
of unskilled workers declined in all subsectors, although the relative decline in the sector with the fastest growth rate of total factor productivity was much stronger than in industries which experienced little technological change (41\% versus $26 \%$ ). On the other hand, relative earnings of unskilled workers in these industries increased somewhat while they remained fairly constant in those industries where productivity growth increased most in the observation period.

Figure 3 Skills ratio and earnings ratio for industries classified by total factor productivity growth.
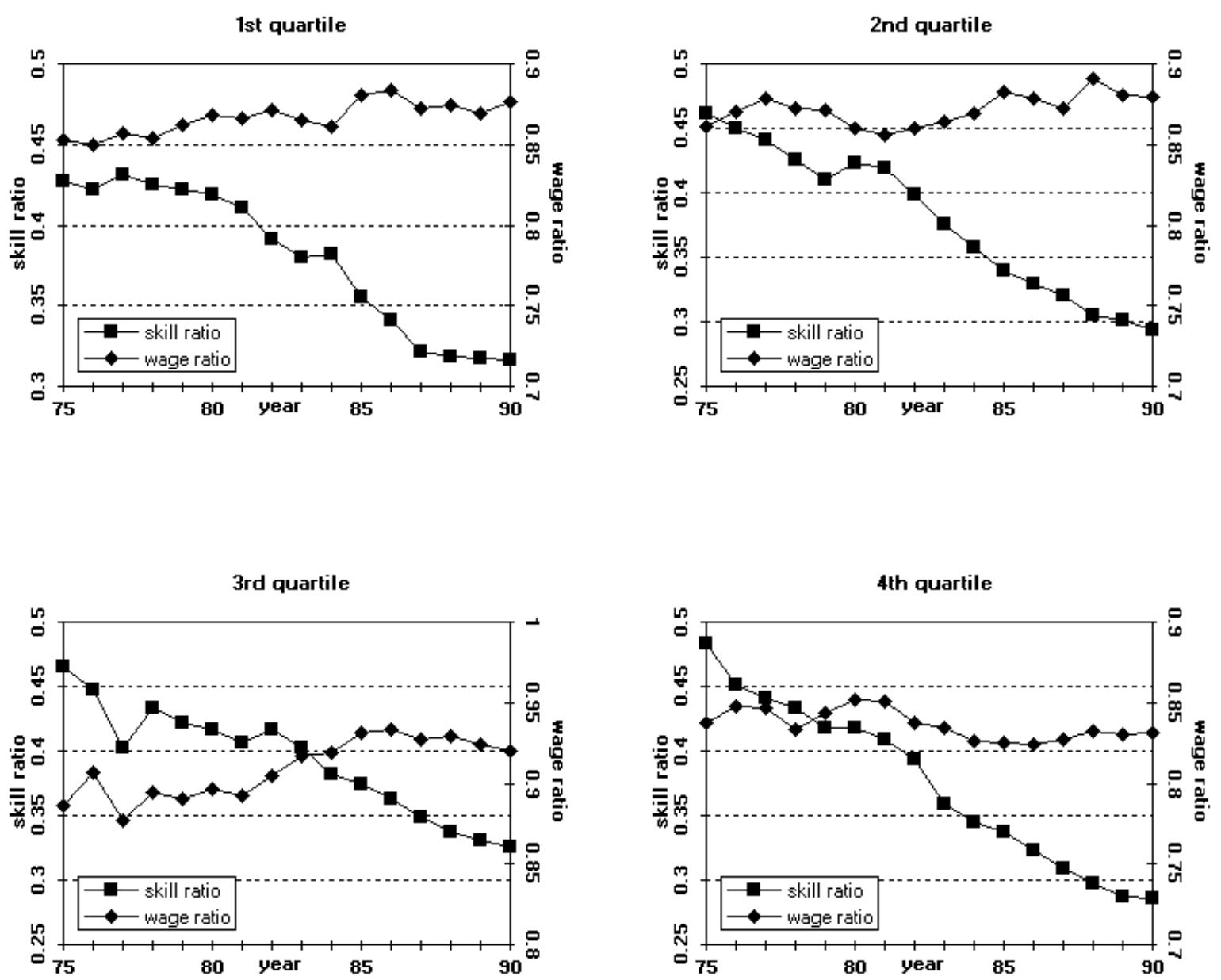

Source: IABS data, own calculations.

growth rate of total factor productivity in an analogous way as explained for the import shares. As has also been shown by Flaig and Steiner (1993), the rate of productivity growth in West German manufacturing industries changed little between 1961 and 1985. 


\section{Substitution between Unskilled and Skilled Labor}

The main question we try to answer here is to what extent the decline in the relative employment of unskilled labor in West German manufacturing industries in the period 1975 to 1990 was affected by the development of relative earnings on the one hand, and other economic factors on the other. We rely on a simple partialequilibrium approach of the labor market as described in section 2. Our working hypothesis will be that the decline in the supply of unskilled male workers has affected all manufacturing industries to a similar extent, and that employment is mainly determined by the demand side of the labor market.

\subsection{Empirical Model}

Our empirical model relates the relative demand for unskilled and skilled workers to their relative earnings and a number of other variables affecting the relative demand for labor. Such a model could be derived on the assumption of profit maximizing or cost minimizing firms facing certain conditions in factor and output markets (Hamermesh, 1993, pp. 33). The model is estimated on the pooled data from about 30 manufacturing industries for the period 1975 to 1990. As already mentioned in the previous section, a detailed data description is contained in the appendix.

To take differences in human capital within unskilled and skilled labor into account, we have disaggregated these two groups by the level of labor market experience, which is an important factor for both the determination of employment and earnings. In particular, economic change due to increased import competition or technological change should mainly have affected older workers who find it more difficult to adjust than workers with little labor market experience. Furthermore, individual earnings also increase substantially with labor market experience (for Germany see, e.g., Steiner and Wagner, 1996), which may or may not reflect the higher productivity level of more experienced workers.

The disaggregation of the two skill groups by their level of labor market experience is based on the social security data described in the appendix. Given that a too fine disaggregation would leave us with an insufficient number of observations in certain industry*formal skill*experience cells, we use five experience groups, that is less than six years, $6-15,16-25,26-35$, and more than 36 years of labor market experience. This skill disaggregation gives us a maximum number of 2,400 observations for the whole time period (30 industries*5 experience groups $* 16$ years). In the estimation, observations referring to cells with less than 20 cases are deleted from the sample. 
We approximate the relative demand for unskilled and skilled labor by the following log-linear function:

$$
\ln \frac{l_{i e t}^{\text {unskilled }}}{l_{\text {iet }}^{\text {skilled }}}=\alpha_{0 i e}+\alpha_{1} \text { trend }+\beta \ln \frac{w_{\text {iet }}^{\text {unskilled }}}{w_{\text {iet }}^{\text {skilled }}}+\gamma^{\prime} \ln Z_{i e t}+\varepsilon_{\text {iet }}
$$

with $l_{\text {iet }}^{(\text {un skilled }}=$ number of (un)skilled workers in industry $i$ with experience level $e$ in year $t$

trend $=$ time trend for the period $1975-1990$, with trend $=1, \ldots, 16$

$w_{\text {iet }}^{(\text {un) skilled }}=$ earnings level of (un)skilled workers

$Z_{i e t} \quad=$ vector of other variables affecting the relative demand for labor

$\alpha_{1}, \beta, \gamma=$ coefficients to be estimated, where $\gamma$ ' is a vector conformable to $Z$

$\alpha_{0 i e} \quad=$ fixed group effect for experience level $e$ in industry $i$

$\varepsilon_{i e t} \quad=$ error term, with $\varepsilon_{i e t} \sim N\left(0, \sigma_{\varepsilon}\right)$.

The time trend should account for trending factors common to all industries, such as the overall decline in the supply of unskilled labor and the effect of skill-biased technological change affecting all industries similarily. Aside from this trend and the earnings ratio, other variables are also included in the vector $Z$ to allow for the possibility that other demand-side factors may affect the relative demand for unskilled. Depending on specific assumptions about firm behavior in an industry, $Z$ may alternatively include the real value of industry output or its price, the real stock of capital or its relative price as well as the stocks or relative prices of other inputs in production, such as energy or material. To check the sensitivity of estimation results, we will present results for various alternative specifications below. The fixed effect, $\alpha_{0 i e}$, should capture all other time-invariant factors which differ between industries and experience groups, and which may or may not be correlated with the other explanatory variables in the model.

Our interest here focuses on the coefficient on the earnings ratio, $\beta$, which gives us an estimate of the substitution elasticity between unskilled and skilled workers, that is the percentage change of the skills ratio for a one-percent change in the earnings ratio. This substitution elasticity is conditional on the time trend and the variables included in the vector $Z$ as well as other factors accounted for by the fixed group effects. As specified in the equation above, the substitution elasticity is assumed to be the same across all industries and experience groups. In the estimations reported below, we will also allow the substitution elasiticity to differ by an industry's import intensity and growth rate of total factor productivity. The maintained assumption that substitution elasticities do not differ between experience groups admittedly is a 
rather restrictive one, but the data unfortunately do not allow for a more flexible specification. ${ }^{15}$

\subsection{Estimation Results}

In Table 1 we present estimation results for various specifications of the model described above for the whole manufacturing sector in the period 1975 to 1990 . The specifications differ with respect to the variables included in the vector $Z$. In all regressions, group specific fixed-effects were highly significant and, according to standard Hausman-tests (see, e.g., Greene, 1993, p. 479) correlated with the regressors in the model. For example, in specification (1) an F-test on the significance of the group-specific fixed effects yielded a value of $F(109,1550)=$ 100.9, while the Hausman-test clearly rejected the null-hypotheses that the unobserved group-specific effects are uncorrelated with the explanatory variables in the model $\left(\chi^{2}(5)=78.36\right)$. Similar test statistics were also obtained for the other specifications of the relative labor demand function reported in Table 1. Hence, we have estimated them conditional on the group-specific fixed-effects.

In specification (1) the skills ratio is regressed on a time trend, the earnings ratio, the value of real output, its capital stock and the relative price of other inputs in that industry. Hence, the estimating equation can be interpreted as a conditional relative labor demand equation derived from cost-minimization with the level of output given and capital treated as a quasi-fixed factor of production (see Flaig and Steiner, 1993). This specification yields an estimate of the substitution elasticity of around -0.5 . The coefficient estimates on the real output and the real capital stock seem rather imprecisely estimated, probably due to the high degree of positive correlation between the two variables. Since the two coefficients are of about equal size but opposite sign, in specification (2) we have restricted them accordingly. ${ }^{16}$ Given that substitution of capital for unskilled labor is more likely than between capital and skilled labor, which could even be complements in production, we expect a higher capital/output ratio to reduce the skills ratio in an industry. The estimated coefficient on this variable has the expected sign, although the effect is not statistically significant. The estimate for the substitution elasticity between unskilled and skilled labor remains unaffected by this change in specification. The same holds for specification (3), where we do not condition on the level of output but instead normalize the price of other inputs by the output price. The substitution elasticity is also not affected if we include the user costs normalized by the output

${ }^{15}$ Due to the relatively small number of observations, separate estimation of the model for each experience group yielded mostly insignificant parameter estimates.

16 An F-test showed that this restriction is not rejected by the data, $\mathrm{F}(1,1550)=0.03$. 
price rather than the capital stock as in specification (4). The user costs of capital as well as the prices of other inputs in production also seem to have no differential impact on the relative demand for skills in this specification.

Since relative skills and their wages are determined together in the labor market, one may suspect that the estimated substitution elasticity suffers from simultaneity bias. In specification (5) we have therefore instrumented the earnings ratio by its lagged value. On the assumption of no serial correlation in the error term, $\varepsilon_{i e t}$, this should be a very good instrument given the high correlation in the earnings ratio. As industy output and the capital stock are also potentially endogenous variables, in specification (5) the capital/output ratio is instrumented by its lagged value as well and the other insignificant variables are left out for efficiency reasons. In this final specification, the estimated substitution elasticity drops markedly to a value of 0.321 (with a standard error of 0.095). This suggests that the estimates in specificatons (1) - (4) are indeed affected by simultaneity bias. On the other hand, the coefficient on the capital/output ratio increases somewhat in size and becomes significant (at the 5\% level), thus supporting the hypothesis on the differential degree of substitution between capital and, respectively, unskilled and skilled labor.

Compared to the estimates of substitution elasticities between different types of labor reported in the few other available studies (Schulte zur Surlage, 1985, Kugler, Müller and Sheldon, 1988, Entorf, 1996, Möller, 1996) in West German manufacturing, our preferred estimate from specification (5) seems to be rather low. For example, Entorf (1996) estimates a substitution elasticity between skilled and unskilled blue collar workers in manufacturing of about -1 for and, depending on the specification, of between -1.5 and 0.5 (sic!) for white-collar workers. However, with the exception of Möller (1996), these studies are based on highly aggregated data, do not differentiate between males and females and rely on a rather different grouping of employees by type of qualification. These estimates are, therefore, not directly comparable to the ones reported here. On the basis of a similar data set as used here, Möller (1996) reports an estimated substitution elasticity of about -1.7 for West German manufacturing. Although it is difficult to tell from his paper how he got to that number, a possible reason for the large difference to our estimate could be that differences between experience groups were not controlled for in his estimation. ${ }^{17}$

17 When we included only industry fixed effects without differentiating between experience groups our model yielded a very high substitution elasticity of about -2.3 . On the other hand, treating the group effects as random instead of fixed had little effect on the estimated substitution elasticities, although changed some of the estimated coefficients for the control variables. However, as indicated by formal tests referred to in the text, the random effects 
Table 1 Estimation results for alternative specifications of the relative labor demand function in German manufacturing, $1975-1990$ ).

\begin{tabular}{|c|c|c|c|c|c|}
\hline \multirow[b]{2}{*}{ Regressor $^{\text {b) }}$} & \multicolumn{5}{|c|}{ Specification } \\
\hline & $(1)$ & $(2)$ & (3) & (4) & (5) \\
\hline constant & $\begin{array}{l}-.803 * * \\
(.331)^{\mathrm{c})}\end{array}$ & $\begin{array}{c}-.824 * * \\
(.329)\end{array}$ & $\begin{array}{l}-.541 * * \\
(.056)\end{array}$ & $\begin{array}{l}-.538 * * \\
(.025)\end{array}$ & $\begin{array}{l}-.802 * * \\
(.147)\end{array}$ \\
\hline trend & $\begin{array}{l}-.031 * * \\
(.002)\end{array}$ & $\begin{array}{l}-.031 * * \\
(.002)\end{array}$ & $\begin{array}{l}-.030 * * \\
(.001)\end{array}$ & $\begin{array}{l}-.030 * * \\
(.001)\end{array}$ & $\begin{array}{l}-.032 * * \\
(.001)\end{array}$ \\
\hline $\ln w^{r}$ & $\begin{array}{l}-.511 * * \\
(.094)\end{array}$ & $\begin{array}{l}-.511 * * \\
(.094)\end{array}$ & $\begin{array}{l}-.521 * * \\
(.093)\end{array}$ & $\begin{array}{l}-.521 * * \\
(.093)\end{array}$ & - \\
\hline $\ln w_{t-1}^{r}$ & - & - & - & - & $\begin{array}{l}-.321 * * \\
(.095)\end{array}$ \\
\hline $\ln y$ & $\begin{array}{r}.043 \\
(.076)\end{array}$ & - & - & - & - \\
\hline $\ln k$ & $\begin{array}{l}-.035 \\
(.071)\end{array}$ & - & $\begin{array}{r}.000 \\
(.042)\end{array}$ & - & - \\
\hline $\ln (k / y)$ & - & $\begin{array}{l}-.038 \\
(.069)\end{array}$ & - & - & - \\
\hline $\ln (k / y)_{t-1}$ & - & - & - & - & $\begin{array}{l}-.124 * \\
(.062)\end{array}$ \\
\hline $\ln \left(p^{k} / p^{x}\right)$ & - & - & - & $\begin{array}{r}.007 \\
(.039)\end{array}$ & - \\
\hline $\ln \left(p^{m} / w^{m}\right)$ & $\begin{array}{l}-.038 \\
(.084)\end{array}$ & $\begin{array}{l}-.042 \\
(.081)\end{array}$ & - & - & - \\
\hline $\ln \left(p^{m} / p^{x}\right)$ & - & - & $\begin{array}{l}-.095 \\
(.160)\end{array}$ & $\begin{array}{l}-.114 \\
(.194)\end{array}$ & - \\
\hline \# obs & 1665 & 1665 & 1665 & 1665 & 1559 \\
\hline $\mathrm{R}^{2}$ adj. & .933 & .933 & .933 & .933 & .937 \\
\hline
\end{tabular}

Notes:

a) dependent variable $=\ln ($ skills ratio $) \equiv \ln \left(l_{\text {iet }}^{\text {unskilled }} / l_{\text {iet }}^{\text {skilled }}\right)$ as defined in the text

b) $w \equiv w_{\text {iet }}^{\text {unskilled }} / w_{\text {iet }}^{\text {skilled }}=$ earnings ratio unskilled / skilled workers as defined in the text $w^{m}=$ median earnings

estimates are likely to be inconsistent. We also tried the first-difference estimator which yielded an estimate of the substitution elasticity of -0.275 , which is very close to our preferred estimate from specification (5). 
$y \quad=$ real value of industry output ${ }^{\mathrm{r}}$

$p^{x}=$ output price

$p^{k}=$ user costs of capital

$p^{m}=$ price of material and energy

c) standard errors are given in parantheses below parameter estimates; a star "*“ indicates significance at the $5 \%$ level, two stars "**" at the $1 \%$ level.

In order to shed some light on sectoral differences with respect to the degree of import competition and technological change, we report estimation results for the respective subsamples of industries in Table 2. As in the previous section, we have split the sample according to the quartile into which an industry's import share or rate of productivity growth falls. Here, we report estimation results for industries with low, middle, and high import intensity and rate of productivity growth, respectively. ${ }^{18}$

Table 2 Estimation results for the relative labor demand function by import intensity and rate of productivity growth, $1975-1990$.

\begin{tabular}{|c|c|c|c|c|c|c|}
\hline \multirow[b]{2}{*}{ Variable $^{\text {a) }}$} & \multicolumn{3}{|c|}{ import intensity } & \multicolumn{3}{|c|}{ rate of productivity growth } \\
\hline & low & middle & high & low & middle & high \\
\hline constant & $\begin{array}{c}-1.390 * * \\
(.320)\end{array}$ & $\begin{array}{l}-.499 * * \\
(.181)\end{array}$ & $\begin{array}{c}-1.138 * \\
(.464)\end{array}$ & $\begin{array}{l}-.264 \\
(.587)\end{array}$ & $\begin{array}{l}-.829 * * \\
(.186)\end{array}$ & $\begin{array}{l}-.826 * * \\
(.270)\end{array}$ \\
\hline trend & $\begin{array}{l}-.032 * * \\
(.002)\end{array}$ & $\begin{array}{l}-.030 * * \\
(.002)\end{array}$ & $\begin{array}{l}-.037 * * \\
(.003)\end{array}$ & $\begin{array}{l}-.022 * * \\
(.006)\end{array}$ & $\begin{array}{l}-.029 * * \\
(.001)\end{array}$ & $\begin{array}{l}-.040 * * \\
(.002)\end{array}$ \\
\hline $\ln w_{t-1}^{r}$ & $\begin{array}{l}-.521 * * \\
(.190)\end{array}$ & $\begin{array}{l}-.220 \\
(.131)\end{array}$ & $\begin{array}{l}-.369 \\
(.205)\end{array}$ & $\begin{array}{l}-.349 \\
(.257)\end{array}$ & $\begin{array}{l}-.592 * * \\
(.125)\end{array}$ & $\begin{array}{r}.144 \\
(.173)\end{array}$ \\
\hline $\ln (k / y)_{t-1}$ & $\begin{array}{l}-.269^{*} \\
(.128)\end{array}$ & $\begin{array}{l}-.011 \\
(.079)\end{array}$ & $\begin{array}{l}-.350 \\
(.191)\end{array}$ & $\begin{array}{r}.053 \\
(.260)\end{array}$ & $\begin{array}{l}-.119 \\
(.078)\end{array}$ & $\begin{array}{l}-.135 \\
(.114)\end{array}$ \\
\hline \# obs & 412 & 908 & 239 & 185 & 969 & 405 \\
\hline $\mathrm{R}^{2}$ adj. & .930 & .936 & .937 & .931 & .937 & .939 \\
\hline
\end{tabular}

Notes:

a) specification is the same as (5) in Table 1; low, middle and high refer to the different quartiles; for definitions of variables see notes to Table 1 .

b) disaggregation of industries by import intensity and rate of productivity growth as described in the text.

c) standard errors are given in parantheses below parameter estimates.

d) a star "*“ indicates significance at the $5 \%$ level, two stars "**“" at the $1 \%$ level.

18 The "middle" category aggregates industries falling into the second and third quartile. 
As the differences in estimated coefficients on the time trend show, the autonomous decline of unskilled labor in industries characterized by relatively high import shares has occurred at a somewhat faster pace $(3.7 \%$ per year) than in the other manufacturing sectors which experienced a reduction in the skills ratio of about $3 \%$. The trend decline of the skills ratio in industries with a low or medium degree of import penetration was quite similar in the observation period, though.

The point estimate of the substitution elasticity of about -0.5 is above average in industries with relatively low import shares, compared to about -0.37 in industries with high import competition. However, the latter elasticity seems rather imprecisely estimated (with a standard error of .205) ${ }^{19}$, and it is thus not clear whether there is in fact a statistically significant difference between these two sectors. The same caveat applies to the estimation results with respect to the capital/output ratio whose negative effect on the skills ratio seems to be of similar size both in industries with a relatively low and high degree of import penetration. In industries with import shares falling in-between these two sectors the coefficient on the earnings ratio is only marginally significant, and the capital/output ratio does seem to have a statistically significant effect on the relative demand for unskilled workers.

The estimation results for the subsamples of industries defined by the rate of total factor productivity growth show that the autonomous decline of the skill ratio in industries with high growth rates in the observation period was markedly higher than in the other sectors. In the former sector, the trend decline in the relative demand of unskilled labor was $4 \%$ per year, almost double the rate experienced in industries characterized by low rates of technological change. The importance of relative earnings for determining the relative demand for skilled and unskilled labor at the industry level also depends on the rate of technological change. The substitution elasticity has its highest absolute value in industries where the rate of technological change neither is particular high nor low. In the latter industries this elasticity is very imprecisely estimated, which is probably due to the small number of remaining observations in this sector. On the other hand, in industries with high rates of productivity growth changes in relative earnings seem to have no statistically significant effect on the relative demand for unskilled labor (the point estimate is even positive).

19 The large standard error can be explained by the relatively small number of observations remaining in this sector. 


\section{Conclusions}

We started from the observation that the German unemployment problem is closely related to the dramatic decline of the employment of unskilled labor in the manufacturing sector since the mid-1970's. This decline occured in all industries within West German manufacturing, but to a varying degree. Although the reduction in the relative supply of unskilled labor has certainly contributed to this development, it is only part of the story. The decline in the relative demand for unskilled labor has also played an important role. On theoretical grounds, it seems likely that both intensified international competition from low-wage countries and skill-biased technological change have adversely affected the demand for unskilled labor. Given the rigidity of relative wages due to the wage setting institutions prevailing in Germany, this will be transmitted to less employment and higher unemployment of unskilled labor. The differential labor market developments in the U.S. and Germany seem to support the hypothesis of a trade-off between more jobs for unskilled workers on the one hand, and a less equal earnings distribution on the other. However, there has been very little previous empirical research on this hypothesis for the German case.

This paper has confirmed the stylized fact that the earnings of unskilled relative to skilled workers in West German manufacturing have on average remained rather stable within the last 20 years or so, although there have been some modest changes between and within industries. Even in industries which had to face high import competition, relative earnings of unskilled workers hardly changed in the observation period. On the other hand, unskilled workers in industries which experienced relatively little technological change could improve their relative earnings position, while those in industries with high productivity growth rates saw their relative earnings declining. However, compared to the dramatic decline of the employment share of unskilled workers in virtually all manufacturing industries, the changes in relative earnings appear rather modest.

On the basis of a simple econometric model, we have analyzed the economic factors which have contributed to this dramatic decline of the employment share of unskilled labor, in particular the extent to which the rigidity of relative earnings may have affected the skills ratio in manufacturing industries. We find that a reduction of the earnings of unskilled relative to skilled workers by $10 \%$ would increase the relative employment level of the unskilled on average by about $3 \%$. Hence, the substitution of unskilled by skilled labor due to differences in relative earnings seems to have been modest compared to the the trend decline in the skills ratio. According to our estimates, this decline has been about $3 \%$ per year for the whole manufacturing sector in the observation period and may have been caused by various factors, in particular the general reduction in the supply of unskilled labor 
and skill-biased technological change common to all industries and experience groups.

As to the potential effects of intensified international competition and technological change, we have found some evidence for the hypothesis that, other things equal, the relative employment of unskilled workers in industries with high import shares has declined more strongly than in those little affected by international competition, but the size of this effect is not dramatic. There is also some evidence which seems to support the hypothesis that the relative employment decline of unskilled workers in industries characterized by relatively high rates of technological change has been somewhat stronger than on average, but this effect, too, explains relatively little of the overall decline in the skills ratio. Furthermore, since the degree of international competition and the rate of technological change are probably interrelated, it seems difficult, if not impossible, to disentangle these two effects.

In view of the U.S. experience, what effects on the employment of unskilled labor could we possibly expect from a hypothetical more dramatic change in relative earnings? Given our estimates of the substitution elasticity between unskilled and skilled labor in West German manufacturing, the likely employment effect of such a change would be noticeable, but certainly not dramatic. Even reductions in the relative earnings of unskilled workers on a scale observed for the U.S. labor market in the 1980's would not be sufficient to bring employment of unskilled workers in West German manufacturing back to the levels we observed in the past, although they could counter the autonomous decline in relative employment of unskilled labor. Of course, given the German wage setting institutions, such large-scale wage reductions seem very unlikely. Furthermore, the welfare implications of such a wage policy seem questionable because the pure substitution effect would work against skilled workers and the overall employment effect remains undetermined.

The present study is just a first step towards a more general explanation of employment and earnings trends in the German economy. Such an analysis would have to take into account the expansion of the service sector and the strong increase in female labor force participation. At least for Germany, very little is known about employment and earnings determination in the service sector and how it is affected by technological change, in particular the ubiquitous spread of information technology. Given the continuing decline in the demand for unskilled labor in manufacturing, expansion of the service sector is widely considered to be the only possible solution to the German unemployment problem. However, to foster employment growth in the service sector would probably require a more flexible wage structure and changes in institutional regulations. At the moment, we know very little about this. 


\section{References}

Abraham, Katherine and Susan N. Houseman, 1995, Earnings Inequality in Germany; in: Richard B. Freeman and Lawrence F. Katz (eds.), Differences and Changes in Wage Structure, University of Chicago Press.

Becker, Irene, 1996, Did Earnings Inequality in the Federal Republic of Germany Increase from the 1960s to the 1980s?, EVS-Projekt Arbeitspapier No. 8, University of Frankfurt/Main.

Bellmann, Lutz and Joachim Möller, 1995, Institutional Influences on Interindustry Wage Differentials, in: Friedrich Buttler et al. (eds.): Institutional Frameworks and Labour Market Performance, London: Routledge.

Berman, Eli, John Bound and Zvi Griliches, 1994, Changes in the Demand for Skilled Labor within U.S. Manufacturing: Evidence from the Annual Survey of Manufactures, Quarterly Journal of Economics, May 1994, 367-397.

Blattner, Niklaus, 1996, Technischer Fortschritt und Arbeitslosigkeit, in: Bernhard Gahlen et al. (eds.): Arbeitslosigkeit und Möglichkeiten ihrer Überwindung, Wirtschaftswissenschaftliches Seminar Ottobeuren, J.C.B. Mohr (Paul Siebeck) Tübingen 1996, 331-358.

Blau, Francine D. and Lawrence M. Kahn, 1996, International Differences in Male Wage Inequality: Institutions versus Market Forces, Journal of Political Economy, 104, 791-837.

Bound, John and George Johnson, 1992, Changes in the Structure of Wages in the 1980's: An Evaluation of Alternative Explanations, American Economic Review, 82, 371392.

Burtless, Gary, 1995, International Trade and the Rise in Earnings Inequality, Journal of Economic Literature, 33, 800-816.

Card, David, Francis Kramarz and Thomas Lemieux, 1996, Changes in the Relative Structure of Wages and Employment: A Comparison of the United States, Canada and France, NBER Working Paper, 5487.

Diewert, Erwin W. and Terence J. Wales, 1992, Quadratic Spline Models for Producer's Supply and Demand Functions, International Economic Review, 33, 705 - 723.

Entorf, Horst, 1996, Strukturelle Arbeitslosigkeit in Deutschland: Mismatch, Mobilität und Technischer Wandel, in: Bernhard Gahlen et al. (eds.): Arbeitslosigkeit und Möglichkeiten ihrer Überwindung, Wirtschafts-wissenschaftliches Seminar Ottobeuren, J.C.B. Mohr (Paul Siebeck) Tübingen 1996, 139-170.

Fitzenberger, Bernd, 1996, Wages, Prices and International Trade: Trends across Industries for an „Export Champion“, Sonderforschungsbereich 178 „Internationalisierung der Wirtschaft", Discussion Paper No. 2-323, University of Konstanz.

Flaig, Gebhard and Viktor Steiner, 1993, Searching for the "Productivity Slowdown": Some Surprising Findings for West-German Manufacturing, Review of Economics and Statistics, 75, 57-65. 
Franz, Wolfgang, 1997, The German Unemployment Problem: What We Know and Do Not Know, Paper presented at the Third GAAC Symposium "Labor Markets in the U.S. and in Germany", Bonn, 10 - 11 June, 1997, Mimeo, ZEW Mannheim.

Franz, Wolfgang, 1995, Die Lohnfindung in Deutschland in einer internationalen Perspektive: Ist das deutsche System ein Auslaufmodell?, Beihefte der Konjunkturpolitik - Applied Economics Quarterly, 43, 31 - 57.

Freeman, Richard B., 1995, Are Your Wages Set in Beijing?, Journal of Economic Perspectives, 9, 15 - 32.

Greene, William H., 1993, Econometric Analysis, MacMillan, New York.

Goux, Dominique and Eric Maurin, 1996, Changes in the Demand for Skilled Labour in France, 1970 - 93, OECD Economic Studies, 1996/2.

Goux, Dominique and Eric Maurin, 1997, The Decline in Demand for Unskilled Labor: An Empirical Analysis Method and its Application to France, INSEE Working Paper, Paris.

Hamermesh, Daniel S., 1993, Labor Demand, Princeton University Press, Princton, NJ.

Hauser, Richard, 1995, Problems of the German Welfare State after Unification, Oxford Review of Economic Policy, 11, 44-58.

Hesse, Helmut, 1996, Internationale Konkurrenz: Ursache von Arbeitslosigkeit und Lohnungleichheit?, in: Bernhard Gahlen et al. (eds.): Arbeitslosigkeit und Möglichkeiten ihrer Überwindung, Wirtschaftswissenschaftliches Seminar Ottobeuren, J.C.B. Mohr (Paul Siebeck) Tübingen 1996, 331-358.

Hunt, Jennifer, 1995, The effect of unemployment compensation on unemployment duration in Germany, Journal of Labor Economics, 13, 88-120.

Katz, Lawrence and Kevin Murphy, 1992, Changes in Relative Wages 1963-1987: Supply and Demand Factors, Quarterly Journal of Economics, February 1992, 35-78.

Koebel, Bertrand, 1996, Tests of Representative Firm Models: Results for German Manufacturing Industries, ZEW Discussion Paper No. 96-16, Mannheim, Germany.

Krueger, Alan B. and Jörn-Steffen Pischke, 1997, Observations and Conjectures on the U.S. Employment Miracle, Paper presented at the Third GAAC Symposium "Labor Markets in the U.S. and in Germany", Bonn, 10 - 11 June, 1997.

Krugman, Paul, 1995a, Growing World Trade: Causes and Consequences, Brookings Papers on Economic Activity, 1/1995, 327-377.

Krugman, Paul, 1995b, Technology, Trade and Factor Prices, NBER Working Paper, 5355, Cambridge (Mass.).

Kugler, Peter, Urs Müller and George Sheldon, 1988, Struktur der Arbeitsnachfrage im technologischen Wandel - Eine empirische Analyse für die Bundesrepublik Deutschland, Weltwirtschaftliches Archiv, 124, 490-500.

Landmann, Oliver and Michael Pflüger, 1996, Arbeitsmärkte im Spannungsfeld von Globalisierung und technologischem Wandel, in: Bernhard Külp (ed.), Arbeitsmarkt und Arbeitslosigkeit, Rudolf Haufe Verlag, Freiburg i. Br. 
Leamer, Eduard E., 1996, In Search of Stolper-Samuelson Effectson U.S. Wages, NBER Working Paper, 5427, Cambridge (Mass.).

Levy, Frank and Richard J. Murane, 1992, U. S. Earnings Levels and Earnings Inequality: A Review of Recent Trends and Proposed Explanations, Journal of Economic Literature, 30, 1333-1381.

Möller, Joachim, 1996, Technological Change, Unemployment, and Recent Trends in Human Capital Formation - Did the German Wage Structure Respond to these Impulses?, Regensburger Diskussionsbeiträge, No. 280, Universität Regensburg.

Möller, Joachim and Lutz Bellmann, 1995, Institutional Influences on Interindustry Wage Differentials, in: Friedrich Buttler et al. (eds.): Institutional Framework and Labor Market Performance, Comparative Views on the U. S. and German Economies, London and New York, Routledge.

Möller, Joachim and Lutz Bellmann, 1996, Qualifikations- und industriespezifische Lohnunterschiede in der Bundesrepublik Deutschland. Eine Untersuchung für das Verarbeitende Gewerbe auf der Basis der IAB-Beschäftigtenstichprobe, ifo Studien, 42, 235 - 272.

Nickell, Stephen and Brian Bell, 1995, The Collapse in Demand for the Unskilled and Unemployment Across the OECD, Oxford Review of Economic Policy, 11, 40-62.

OECD (1996): Employment Outlook, chapter 3, Paris.

Richardson, J. David, 1995, Income Inequality and Trade: How to Think, What to Conclude, Journal of Economic Perspectives, 9, 33 - 56.

Sachverständigenrat (German Council of Economic Experts), 1994, Jahresgutachten 1994/95 des Sachverständigenrates zur Begutachtung der gesamtwirtschaftlichen Entwicklung.

Schulte zur Surlage, Rolf, 1985, Qualifikationsstruktur der Arbeitsnachfrage, Campus, Frankfurt/Main.

Siebert, Horst, 1997, Labor Market Rigidities and Unemployment in Europe, Kiel Working Paper No. 787, Institut für Weltwirtschaft, Kiel.

Steiner, Viktor, 1997, Extended Benefit Entitlement Periods and the Duration of Unemployment in West Germany, ZEW Discussion Paper 97-14, Mannheim.

Steiner, Viktor and Kersten Wagner, 1996, Has Earnings Inequality in Germany Changed in the 1980's?, ZEW Discussion Paper 96-32, Mannheim.

Steiner, Viktor and Bruno Kaltenborn, 1995, Arbeitsmarktdynamik, Langzeitarbeitslosigkeit und der Beitrag der Arbeitsmarktpolitik, in: Wolfgang Franz and Viktor Steiner (eds.): Der westdeutsche Arbeitsmarkt im strukturellen Anpassungsprozeß, Band 3, Nomos.

Wood, Adrian, 1995, How Trade Hurt Unskilled Workers, Journal of Economic Perspectives, 9, $57-80$. 


\section{Data Appendix}

This study matches sectoral information from the disaggregated national accounts and individual-level employment as well as earnings information from the Employment Register of the Federal Labour Office, the so-called "IABBeschäftigtenstichprobe", IABS for short (for details see Steiner and Wagner, 1996). The IABS is a $1 \%$ random sample of all dependently employed persons living in Germany who are covered by the social security system. The data base from which the IABS is drawn includes about 80 percent of all employed people in Germany. In each of these years, about 200,000 individuals were randomly sampled from the population. For our empirical analysis, the sample is restricted to full-time employed males in manufacturing, apprentices are excluded. Females are not considered here because the data do not contain information on hours worked.

Aside from the very large sample size, the greatest advantage of the IABS is its supposedly reliable earnings data. Employers are legally requested to report earnings of their employees covered by the social security system to the Federal Bureau of Labor. This information is then passed on to the social security agencies where it is used as the basis for the calculation of the amount of the public pension of each covered employee. (This data base is, therefore, also referred to as social security data.) The exact amount of gross earnings has to be reported, and there are legal sanctions for false reporting by the employer. However, there are also some shortcomings of the earnings data in the IABS. First, earnings do not include social security contribution paid directly by the employer. Second, fringe benefits are included, but cannot be separated from "normal" earnings. Since the way fringe benefits are reported in the IABS has changed between 1983 and 1984, there is a severe break in the earnings data. However, except for graduates this does not affect the median of the earnings distribution for (see Steiner and Wagner, 1996), which we use as our earnings measure here.

The IABS contains information on an individual's vocational/educational qualification and age. This information is used to construct skill groups as defined by the level of formal qualification and labor market experience. For the empirical analysis, the six vocational/ educational groups listed in Table A1 are aggregated into three: no vocational/education degree (1), vocational degree/higher education (2), (3) and (5), and university/polytechnical degree (4) and (6). Following usual practice, we define an individual's potential labor market experience as: age years of schooling - six years. Years of schooling are derived from the highest vocational/ educational degree as summarized in Table A1. 
Table A1. Years of schooling by vocational/educational category

\begin{tabular}{ll}
\hline \hline & \\
Vocational degree/higher education & $\begin{array}{c}\text { Years of } \\
\text { schooling }\end{array}$ \\
\hline (1) $\quad$ No vocational degree, no higher education & 10 \\
(2) $\quad$ Vocational degree, but no university entry level degree ${ }^{\text {a) }}$ & 12.125 \\
(3) University entry level degree & 13 \\
(4) Polytechnical degree ${ }^{\text {b) }}$ & 15 \\
(5) Vocational degree and university entry level degree & 15.125 \\
(6) University degree & 18 \\
\hline a) "allgemeine/fachgebundene Hochschulreife" \\
b) "Fachhochschulabschluss \\
\hline \hline
\end{tabular}

Source: Steiner and Wagner (1996).

The IABS also contains information on an individual's industry affiliation at the three digit-level, which can be aggregated to the two-digit level available in the national account data referred to below. The resulting 30 two-digit industries comprising the manufacturing sector are listed in Table A2. The last two columns of the table contain the classsification industries by quartile of import share and growth rate of total factor productivity, respectively.

From the disaggregated yearly national account data provided on tape by the Federal Statistical Offices we obtained infomation on the real gross output, its price level, real value added, nominal intermediate inputs, and the real value of the capital stock in each industry. An implicit price index for intermediate inputs for each industry was derived by dividing nominal intermediate inputs by the difference between real gross output and real value added. The user costs of capital were provided by Betrand Koebel and calculated as described in Koebel (1996). He also provided us with a measure of total factor productivity growth for each industry based on a modified growth accounting procedure as described in Diewert and Wales (1992, p. 719). 
Table A2. Industry Classification in the IABS and in the National Accounts (NA)

\begin{tabular}{|c|c|c|c|c|}
\hline IABS & NA & Industries & $\begin{array}{l}\text { Import } \\
\text { quartile }\end{array}$ & $\begin{array}{r}\text { TFPG } \\
\text { quartile }\end{array}$ \\
\hline $9-10$ & 14 & Chemical Products & 3 & 4 \\
\hline 11 & 15 & Petroleum Products & 3 & 1 \\
\hline 12 & 16 & Synthetic Materials & 2 & 4 \\
\hline 13 & 17 & Rubber Products & 3 & 3 \\
\hline 14 & 18 & Stone and Clay & 1 & 4 \\
\hline 15 & 19 & Fine Ceramics & 3 & 3 \\
\hline 16 & 20 & Glass & 2 & 4 \\
\hline 17 & 21 & Iron & 3 & 2 \\
\hline 18 & 22 & Non-ferrous Metals & 4 & 2 \\
\hline 19 & 23 & Foundry & 1 & 2 \\
\hline $20-21$ & 24 & Transforming Metal & 1 & 2 \\
\hline $22-24$ & 25 & Fabricated Metal & 1 & 3 \\
\hline $25-27$ & 26 & Machinery & 2 & 2 \\
\hline $28-30$ & 28 & Vehicles and Repairs & 2 & 3 \\
\hline 31 & 29 & Shipbuilding & 2 & 2 \\
\hline 32 & 30 & Airplanes and Space Shuttles & 4 & 1 \\
\hline 33 & 27 & Data Processing and Office Equipment & 4 & 4 \\
\hline 34 & 31 & Electrical Appliances and Repairs & 2 & 4 \\
\hline $35-36$ & 32 & Precision and Optical Instruments & 4 & 4 \\
\hline 37 & 33 & Metal Products & 2 & 3 \\
\hline $38-39$ & 34 & Musical Instruments, Toys, Jewelry & 4 & 1 \\
\hline 40 & 35 & Woodwork & 3 & 1 \\
\hline $41-42$ & 36 & Wood Processing & 1 & 3 \\
\hline 43 & $37-38$ & Paper & 3 & 2 \\
\hline 44 & 39 & Printing and Publishing & 1 & 3 \\
\hline $45-46$ & 40 & Leather & 4 & 1 \\
\hline $47-51$ & 41 & Textiles & 4 & 3 \\
\hline $52-53$ & 42 & Apparel & 3 & 1 \\
\hline $54-57$ & $43-44$ & Food, Beverages & 2 & 1 \\
\hline 58 & 45 & Tobacco & 1 & 1 \\
\hline
\end{tabular}

Note: Quartiles with respect to an industrie's import share (TFPG = rate of total factor productivity growth) are denoted by 1 to 4, where 1 refers to an industry belonging to the lowest quartile and 4 to the highest quartile. The industries 15, 27, 29, 30, 34, 42 and 45 (NA-classification) are 
dropped in the regressions because of an insufficient number of observations in the respective industry*skillgroup*experience group cell. 